\title{
Isolation and characterization of polyhydroxyalkanoate and exopolysaccharide producing Bacillus sp. PS1 isolated from sugarcane field in Bhilai, India
}

\author{
Prashant Shukla*, Nimesh Patel, Raja Mohan Rao, Jini Shukla, Seema Verma, Shobha Jha and Shobha Gawri
}

G.D. Rungta College of Science and Technology, Kohka-kurud Road, Bhilai, CG, India

\begin{abstract}
Polyhydroxyalkanoates (PHA) and exopolysaccharide (EPS) are important biopolymers. Bacteria produce polyhydroxyalkanoate by fermenting sugar and lipids as a mechanism of storing carbon and energy under unbalanced growth condition. A bacterium of Bacillus group was isolated from sugarcane field in Bhilai which produced PHA and EPS. It was aerobic, Gram positive, rod shaped, endospore forming and catalase producing bacterium. It was able to grow up to $14 \% \mathrm{NaCl}$ concentration, $\mathrm{pH}$ range from 3 to 10 and temperature range from $27^{\circ} \mathrm{C}$ to $70^{\circ} \mathrm{C}$. Maximum yield of PHA was $38.5 \mathrm{mg} / \mathrm{ml}$ at $40^{\circ} \mathrm{C}$ while at $60^{\circ} \mathrm{C}$ yield was $34.5 \mathrm{mg} / \mathrm{ml}$. Likewise maximum yield of EPS was $18.5 \mathrm{mg} / \mathrm{ml}$ at $37^{\circ} \mathrm{C}$. The bacterium has other biotechnological aspects also which is evident from the fact that it has catalase activity up to $65^{\circ} \mathrm{C}$ and produces urease.
\end{abstract}

Keywords: Bacterium; PHA; Exopolysaccharide; Catalase; Bacillus

\section{Introduction}

Microorganisms are important organisms from industrial point of view of which bacteria are most important. Various enzymes like amylase, catalase, cellulase, urease etc. are being produced from bacteria [1-6]. Poly hydroxyalkanoate (PHA) and exopolysaccharide are also produced from bacteria [7-10]. PHAs were seen as the ideal material for replacing petrochemical based plastics. With the development of consciousness about the safety of environment materials which are biodegradable are becoming replacement options of petrochemical based plastics [11].

Microorganisms synthesize a wide spectrum of multifunctional polysaccharides including intracellular polysaccharides, structural polysaccharides and extracellular polysaccharides or exopolysaccharides (EPS). Exopolysaccharides are high-molecular-weight polymers, composed of sugar residues. EPS are secreted by microorganisms into their surrounding environment. Exopolysaccharides are extensively used as thickening and gelling agents in a wide range of industrial products and processes [12]. Likewise catalase which breaks hydrogen peroxide into water and oxygen is used for removing pollution caused due to $\mathrm{H}_{2} \mathrm{O}_{2}$ presence in industrial effluents therefore is an important enzyme isolated from bacteria. PHA and exopolysaccharide producing bacteria have been isolated from soils of sugarcane fields, ammunition polluted soils, effluents of distillery, sewage etc. [13-17].

The present work was undertaken for isolation of PHA and exopolysaccharide producing bacteria from soil and to optimize the medium. The objective of study was to integrate PHA and exopolysaccharide extraction so that exopolysaccharide can be extracted from the broth and PHA from the cells without any loss of both the polymers. The morphological, physiological and biochemical tests were also performed in order to characterize various property of bacterium.

\section{Materials and Methods}

Soil from sugarcane field was brought to the laboratory in a presterilized container for isolation of bacteria with prospective PHA producing properties. Soil was air dried for 2 days and bacteria was cultured using serial dilution method on nutrient agar media (NAM) plates.

\section{Culture media}

Media used for culture of bacteria from soil was nutrient agar media which contain peptone (5g), beef extract (3g), $\mathrm{NaCl}(5 \mathrm{~g})$, agar $(15 \mathrm{~g})$, distilled water $(1000 \mathrm{ml})$. For production of PHA and EPS by bacterium 3 different broth medium were used. Broth1 nutrient broth which contain peptone ( $5 \mathrm{~g})$, beef extract $(3 \mathrm{~g}), \mathrm{NaCl}(5 \mathrm{~g})$, distilled water $(1000 \mathrm{ml})$ and broth 2 was Luria broth which while broth 3 contain beef extract $(1 \mathrm{~g})$, sucrose $(5 \mathrm{~g}), \mathrm{NaCl}(5 \mathrm{~g})$ per liter.

Broth 3 medium was further modified to achieve optimum medium composition for PHA and EPS production. Modified 1 broth 3 medium contain $0.1 \%$ Beef extract, $5 \%$ Sucrose, $0.5 \% \mathrm{NaCl}$, Modified 2 broth 3 medium contain $0.15 \%$ Beef extract, $5 \%$ Sucrose, $0.5 \% \mathrm{NaCl}$, Modified 3 broth 3 medium contain $0.025 \%$ Beef extract, 10\% Sucrose, $0.5 \% \mathrm{NaCl}$, Modified 4 broth 3 medium contain $0.05 \%$ Beef extract , $15 \%$ Sucrose, $0.5 \% \mathrm{NaCl}$.

\section{Methods}

The bacterium with mucoid colony was isolated and pure cultured in nutrient agar medium at $37^{\circ} \mathrm{C}$ temperature by serial dilution method for further tests. Various morphological and physiological tests were performed, for which nutrient agar medium was used as culture medium. Colony morphology was determined by growing the bacterium on nutrient agar medium at $37^{\circ} \mathrm{C}$ temperature. Cell morphology of bacterium growing at $37^{\circ} \mathrm{C}$ temperature was determined by gram staining and endospore staining. Physiological characterization of bacterium was done by testing the property of the bacterium to be

${ }^{*}$ Corresponding author: Dr. Prashant Shukla, G.D. Rungta College of Science and Technology, Kohka-kurud Road, Bhilai, CG, India,Tel: 91-9300468815; E-mail: prashant19782000@gmail.com

Received December 10, 2010; Accepted March 29, 2011; Published March 31 2011

Citation: Shukla P, Patel N, Mohan Rao R, Shukla J, Verma S, et al. (2011) Isolation and characterization of polyhydroxyalkanoate and exopolysaccharide producing Bacillus sp. PS1 isolated from sugarcane field in Bhilai, India. J Microbial Biochem Technol 3: 033-035. doi:10.4172/1948-5948.1000048

Copyright: ( $\odot 2011$ Shukla $P$, et al. This is an open-access article distributed unde the terms of the Creative Commons Attribution License, which permits unrestricted use, distribution, and reproduction in any medium, provided the original author and source are credited. 
Citation: Shukla P, Patel N, Mohan Rao R, Shukla J, Verma S, et al. (2011) Isolation and characterization of polyhydroxyalkanoate and exopolysaccharide producing Bacillus sp. PS1 isolated from sugarcane field in Bhilai, India. J Microbial Biochem Technol 3: 033-035. doi:10.4172/19485948.1000048

able to grow at different temperature $\left(20^{\circ} \mathrm{C}-80^{\circ} \mathrm{C}\right), \mathrm{pH}(3-11)$ and $\mathrm{NaCl}$ Concentration (2\%-16\%). Then a range of biochemical tests were done to check the biochemical property of bacterium. These tests were catalase, indole, methyl red, VP, citrate utilization, casein hydrolysis, gelatin hydrolysis, starch hydrolysis, urea hydrolysis, nitrate reduction, $\mathrm{H} 2 \mathrm{~S}$ production, tween 80 hydrolysis, $\mathrm{O} / \mathrm{F}$, DNase production and litmus test. To observe maximum PHA and EPS production bacterium was cultured at $37^{\circ} \mathrm{C}$ temperature in 3 different broths medium and in 4 different modification of broth 3. PHA and EPS were also observed in broth 3 medium at 4 different temperatures that was $37^{\circ} \mathrm{C}, 40^{\circ} \mathrm{C}$, $50^{\circ} \mathrm{C}, 60^{\circ} \mathrm{C}$. For PHA and EPS the bacterium was grown in broth for one week. Instead of two separate methods of isolating PHA and exopolysaccharide the methods to harvest them were integrated.

\section{Method to harvest the polymers}

$10 \mathrm{ml}$ broth containing bacterial cultured was centrifuged for 20 minutes at $1500 \mathrm{rpm}$.

The bacterial pellet was taken for PHA extraction and the supernatant for extraction of exopolysaccharide.

Supernatant was again centrifuged for 20minutes at 1500rpm to separate remaining cells. $5 \mathrm{ml}$ supernatant was taken in fresh tube and 3 times volume (that was $15 \mathrm{ml}$ ) ethanol was added to it and was incubated for 1 hour to precipitate the exopolysaccharide.

Bacterial pellet was resuspended in $5 \mathrm{ml}$ distilled water and lysed by sodium hypochlorite at $37^{\circ} \mathrm{C}$ for 1 hour. The lysed mass was centrifuged at 10,000 rpm for 10 minutes and the resulting pellet was washed first with distilled water and then with acetone and alcohol (1:1). PHA was precipitated by addition of chloroform. The PHA recovered after evaporation of chloroform was weighed and $10 \mu \mathrm{g}$ of it was digested in $\mathrm{H}_{2} \mathrm{SO}_{4}$ at $100{ }^{\circ} \mathrm{C}$ for 10 minutes. It was estimated at $235 \mathrm{~nm}$ against crotonic acid as standard. The digested sample was scanned from 190 $700 \mathrm{~nm}$ against $\mathrm{H}_{2} \mathrm{SO}_{4}$ standard [3].

Catalase was tested using hydrogen peroxide and production of bubbles was taken as an indication for production of catalase enzyme by the bacterial cells. Presence of activity of catalase was tested by titrating against potassium permanganate and sulphuric acid.

\section{Results}

The morphological, physiological and biochemical characters of the bacterium are given in (Table 1, Table 2 and Table 3 ) respectively. Amount of PHA and exopolysaccharide produced by the bacterium in different media are given in (Table 4). In (Table 5) the amount of

\begin{tabular}{|c|c|c|}
\hline S.No. & Test & Results \\
\hline 1. Colony Morphology & & Circular \\
\hline A & Configuration & Wavy \\
\hline B & Margin & Elevated \\
\hline C & Elevation & - \\
\hline D & Pigment & Opaque \\
\hline E & Opacity & Smooth \\
\hline F & Surface & Positive \\
\hline 2. Cell Morphology & & Rods \\
\hline A & Gram Stain & Present \\
\hline B & Cell Shape & - \\
\hline C & Arrangement & Single, Group, Two cell, Chains \\
\hline D & Endospores & Motility \\
\hline E & & \\
\hline
\end{tabular}

Table 1: Results of Morphological tests performed on the bacterial strain at $37^{\circ} \mathrm{C}$ temperature.

\begin{tabular}{|c|c|c|}
\hline S.No. & Growth Condition & Results \\
\hline \multicolumn{3}{|c|}{ 1. Growth at different temperature } \\
\hline A & $20^{\circ} \mathrm{C}$ & - \\
\hline$B$ & $25^{\circ} \mathrm{C}$ & - \\
\hline C & $27^{\circ} \mathrm{C}$ & + \\
\hline $\mathrm{D}$ & $30^{\circ} \mathrm{C}$ & + \\
\hline$E$ & $37^{\circ} \mathrm{C}$ & + \\
\hline $\mathrm{F}$ & $47^{\circ} \mathrm{C}$ & + \\
\hline G & $57^{\circ} \mathrm{C}$ & + \\
\hline $\mathrm{H}$ & $60^{\circ} \mathrm{C}$ & + \\
\hline 1 & $67^{\circ} \mathrm{C}$ & + \\
\hline $\mathrm{J}$ & $70^{\circ} \mathrm{C}$ & + \\
\hline $\mathrm{K}$ & $77^{\circ} \mathrm{C}$ & + \\
\hline $\mathrm{L}$ & $80^{\circ} \mathrm{C}$ & - \\
\hline \multicolumn{3}{|c|}{ 2. Growth at different pH } \\
\hline A & 3 & + \\
\hline B & 4 & + \\
\hline $\mathrm{C}$ & 5 & + \\
\hline $\mathrm{D}$ & 6 & + \\
\hline$E$ & 7 & + \\
\hline $\mathrm{F}$ & 8 & + \\
\hline G & 9 & + \\
\hline $\mathrm{H}$ & 10 & + \\
\hline 1 & 11 & + \\
\hline \multicolumn{3}{|c|}{ 3. Growth at different conc. Of $\mathrm{NaCl}$} \\
\hline A & $2 \%$ & + \\
\hline B & $4 \%$ & + \\
\hline C & $6 \%$ & + \\
\hline D & $8 \%$ & + \\
\hline $\mathrm{E}$ & $10 \%$ & + \\
\hline $\mathrm{F}$ & $12 \%$ & + \\
\hline G & $14 \%$ & + \\
\hline $\mathrm{H}$ & $16 \%$ & - \\
\hline
\end{tabular}

Table 2: Results of physiological tests performed on the bacterial strain at various growth conditions.

\begin{tabular}{|c|c|c|}
\hline S. No. & Test & Results \\
\hline 1 & Catalase & + \\
\hline 2 & Indole & - \\
\hline 3 & Methyl Red & - \\
\hline 4 & VP & + \\
\hline 5 & Citrate utilization & + \\
\hline 6 & Casein hydrolysis & + \\
\hline 7 & Gelatin hydrolysis & - \\
\hline 8 & Starch hydrolysis & + \\
\hline 9 & Urea hydrolysis & + \\
\hline 10 & Nitrate reduction & + \\
\hline 11 & $\mathrm{H} 2 \mathrm{~S}$ production & - \\
\hline 12 & Tween 80 hydrolysis & + \\
\hline 13 & $\mathrm{O} / \mathrm{F}$ & $\mathrm{O} / \mathrm{F}$ \\
\hline 14 & DNase production & - \\
\hline 15 & Litmus test & Proteolysis \\
\hline
\end{tabular}

Table 3: Results of Biochemical tests performed on the bacterial strain.

PHA and exopolysaccharide produced by the bacterium in different modification of broth 3 is given. There is also variation in amount of PHA and exopolysaccharide produced by the bacterium at different temperatures which is given in Table 6. The highest amount of PHA produced was $38.5 \mathrm{mg} / \mathrm{ml}$ at $40^{\circ} \mathrm{C}$ and $34.5 \mathrm{mg} / \mathrm{ml}$ at $60^{\circ} \mathrm{C}$. Only one major peak was visible at $340 \mathrm{~nm}$ which indicated that only one type of 
Citation: Shukla P, Patel N, Mohan Rao R, Shukla J, Verma S, et al. (2011) Isolation and characterization of polyhydroxyalkanoate and exopolysaccharide producing Bacillus sp. PS1 isolated from sugarcane field in Bhilai, India. J Microbial Biochem Technol 3: 033-035. doi:10.4172/19485948.1000048

PHA was produced. Highest amount of EPS produced was $18.5 \mathrm{mg} / \mathrm{ml}$ at $37^{\circ} \mathrm{C}$. Catalase activity revealed that it is active up to $65^{\circ} \mathrm{C}$ and there is no difference in the amount of activity shown at different temperatures $\left(37^{\circ} \mathrm{C}, 40^{\circ} \mathrm{C}, 50^{\circ} \mathrm{C}, 60^{\circ} \mathrm{C}\right.$ and $\left.65^{\circ} \mathrm{C}\right)$.

\section{Discussion}

The bacterium isolated from the soil of sugarcane in Bhilai is proposed to be a member of Bacillus group on the basis of its morphological and biochemical tests. The bacterium is rod shaped, endospore producing, and catalase positive and aerobic and on these criteria it can be placed in the Bacillus group. The physiological properties of the bacterium is remarkable as it able to grow at $\mathrm{pH} 3-\mathrm{pH}$ 10. It is also able to grow at $\mathrm{NaCl}$ concentrations up to $14 \%$. The most remarkable physiological property of the bacterium is the ability to grow at wide range of temperatures. This is also shown by the catalase activity as the enzyme shows no difference in its activity from $37^{\circ} \mathrm{C}$ to $77^{\circ} \mathrm{C}$. PHA is produced by the bacterium and its production was tested at different temperatures. Likewise exopolysaccharide production was also tested at the same temperatures.

The change in temperature changes the amount of PHA and EPS production. PHA production increased as the temperatures increased while the amount of exopolysaccharide decreased with the increase in temperature. PHA production was highest at $60^{\circ} \mathrm{C}$ in broth 3. Similar quantity was obtained of PHA and exopolysaccharides from samples which were processed separately from those samples where PHA and exopolysaccharides were obtained in a single sample (Table 7). With the increase in temperatures the amount of PHA production also increased and at lower temperatures EPS production was favorable. Various other workers have given the amount of PHA produced in terms of dry

\begin{tabular}{|c|c|c|c|}
\hline S. No. & BROTH & \multicolumn{2}{|c|}{ Results } \\
\hline & & PHA (mg/ml) & EPS (mg/ml) \\
\hline 1. & Broth 1 & 12.8 & 8.5 \\
\hline 2. & Broth 2 & 8.5 & 10.0 \\
\hline 3. & Broth 3 & 20 & 18.5 \\
\hline
\end{tabular}

Table 4: Amount of PHA and EPS produced by bacterium in different medium at $37^{\circ} \mathrm{C}$ temperature.

\begin{tabular}{|c|c|c|c|}
\hline S.No. & Modified Broth 3 & \multicolumn{2}{|c|}{ Results } \\
\hline & & PHA (mg/ml) & EPS (mg/ml) \\
\hline 1 & Modified :1 & 7.7 & 7.1 \\
\hline 2 & Modified :2 & 38.5 & - \\
\hline 3 & Modified :3 & 5.7 & 2.1 \\
\hline 4 & Modified :4 & 5.7 & 7.1 \\
\hline
\end{tabular}

Table 5: Amount of PHA and EPS produced by bacterium in different modified broth 3 medium at $40{ }^{\circ} \mathrm{C}$ temperature.

\begin{tabular}{|c|c|c|c|}
\hline S. No. & Temperature & \multicolumn{2}{|c|}{ Result } \\
\hline & & PHA (mg/ml) & EPS (mg/ml) \\
\hline 1 & $37^{\circ} \mathrm{C}$ & 20 & 18.5 \\
\hline 2 & $40^{\circ} \mathrm{C}$ & 24.5 & 12 \\
\hline 3 & $50^{\circ} \mathrm{C}$ & 27.3 & 8 \\
\hline 4 & $60^{\circ} \mathrm{C}$ & 34.5 & 2 \\
\hline
\end{tabular}

Table 6: Production of PHA and EPS in broth 3 medium at different temperatures.

\begin{tabular}{|c|c|c|c|}
\hline S. No. & Method & PHA $\mathbf{( m g / m l )}$ & EPS $\mathbf{( m g / m l )}$ \\
\hline 1 & Only PHA & 25 & - \\
\hline 2 & Only EPS & - & 12.3 \\
\hline 3 & $\begin{array}{c}\text { PHA and EPS both from same } \\
\text { sample }\end{array}$ & 24.3 & 12 \\
\hline
\end{tabular}

Table 7: Amount of PHA and EPS from different methods. weight which we are avoiding as the work done here is for optimizing the medium for PHA production [15-16].

The results show that with the bacteria producing both PHAs and exopolysaccharides both can be obtained from the same sample without loss of quantity of both polymers. This will reduce time and labour in the extraction method.

\section{Conclusion}

It can be concluded from the above study that PHA and exopolysaccharide producing bacteria can be isolated from sugarcane field. Production of PHA is higher than the EPS yield will be lower and vice versa. The results also show that at higher temperatures PHA production is favored and at lower temperatures EPS production is favored.

\section{References}

1. Adeleye Al (1990) Production and control of extracellular a-amylase in Micrococcus varians. J Bas Microbiol 30: 723-727.

2. Kim JK, Mulrooney SB, Hausinger RP (2005) Biosynthesis of active Bacillus subtilis urease in the absence of known urease accessory proteins. J Bacterio 187: 7150-7154

3. Law JH, Slepecky RA (1961) Assay of poly-b-hydrohybutyric acid. J Bacterio 82: 33-36.

4. Lee SY, Choi JI (1999) Polyhydroxyalkanoates: Biodegradable polymers In: Demain AL, Davies J. E. (eds). Manual of Industrial Microbiology and Biotechnology. ASM press, Washington, D.C., 2ed, p. 616-627.

5. Yumoto I, Ichihashi D, Iwata H, Istokovics A, Ichise N, et al. (2000) Purification and characterization of a catalase from the facultatively psychrophilic bacterium Vibrio rumoiensis S-1 $1^{\top}$ exhibiting high catalase activity. J Bacteriol 182: 1903 1909

6. Achal V, Pan X (2010) Characterization of urease and carbonic anhydrase producing bacteria and their role in calcite precipitation. Curr Microbio

7. Duta FP, França FP, Lopes LMA (2005) Optimization of culture conditions fo exopolysaccharides production in Rhizobium $\mathrm{sp}$ using the response surface method. Elec J Biotech 9, fulltext-7.

8. Lima TCS, Grisi BM, Bonato MCM (1999) Bacteria isolated from sugarcane agro ecosystem: their potential production of polyhydroxyalkanoates and resistance to antibiotics. Revista de Microbiología 30: 241-224.

9. Matsuyama H, Kawasaki K, Yumoto I, Shida O (1999) Microbacterium kitaminese sp. nov., a new polysaccharide-producing bacterium isolated from the wastewater of sugar-beet factory. Int J Syst Bacteriol 49: 1353-1357.

10. Tajima K, Igari T, Nishimura D, Nakamura M, Satoh Y, et al. (2003) Isolation and characterization of Bacillus sp. INT005 accumulating Polyhydroxyalkanoate (PHA) from gas field soil. J Biosc Bioengg 95: 77-81.

11. Ribera RG, Monteoliva M, Ramos A (2001) Production of polyhydroxyalkanoates by Pseudomonas putida KT2442 harboring pSK2665 in waste water from olive mills (alpechín). J Biotechnol 4: 116-119.

12. Horikoshi K (1999) Alkaliphiles: Some applications of their products for Biotechnology. Microbiol Mol Biol Rev 63: 735-750.

13. Nubia M, Ivonne, Dionisio M, Victoria G, Dolly R, et al. (2007) Bioprospecting and characterization of poly-b-hydroxyalkanoate (PHAs) producing bacteria isolated from Colombian sugarcane producing areas. Afri J Biotechnol 6: 1536 1543

14. Mizuno K, Ohta A, Hyakutake M, Ichinomiya $Y$ and Tsuge $T$ (2010) Isolation of polyhydroxyalkanoate-producing bacteria from a polluted soil and characterization of the isolated strain Bacillus cereus YB-4. Polymer Degradation and Stability 95: 1335-1339.

15. Sayyed RZ, Gangrude NS (2010) Poly-B-hydroxybutyrate production by Pseudomonas sp. RZS 1 under aerobic and semi-aerobic conditions. Ind J Exp Biol 48: 942-947

16. Joshi PA, Jaysawal SR (2010) Isolation and characterization of Poly-Bhydroxyalkanoate producing bacteria from sewage sample Journal of Cell and Tissue Research 10: 2165-2168. 